\title{
Identifying the Constraints of Traditional Zoning Regulation: Form-Based Codes as Alternatives to Urban Communities
}

\author{
Emad Mohammed Qurnfulah, Abdulmuakhir Dalhat Isah* \\ Department of Urban and Regional Planning, Faculty of Environmental Design, King Abdulaziz University, \\ Jeddah, KSA \\ Email: ^adalhat@stu.kau.edu.sa
}

How to cite this paper: Qurnfulah, E. M., \& Isah, A. D. (2019). Identifying the Constraints of Traditional Zoning Regulation: Form-Based Codes as Alternatives to Urban Communities. Current Urban Studies, 7, 539-550.

https://doi.org/10.4236/cus.2019.74027

Received: October 6, 2019

Accepted: November 8, 2019

Published: November 11, 2019

Copyright () 2019 by author(s) and Scientific Research Publishing Inc. This work is licensed under the Creative Commons Attribution International License (CC BY 4.0).

http://creativecommons.org/licenses/by/4.0/

\begin{abstract}
Form-based codes (FBCs) have recently been introduced as a viable alternative to the traditional zoning regulations. They are land regulations where building form rather than solely land use is the guiding principle of the code. This is in contrast to the traditional (conventional) zoning regulation which separates land by uses for the purpose of maintaining an orderly separation of incompatible uses. This study is set to undertake a critical comparative review of form-based code against the traditional zoning codes. The comparative review seeks to carefully review the constraints of the traditional building regulations with the aim of identifying the prospects of form-based code implementation in urban communities. Secondary data will be the main source of data for this study, and it will be gotten from existing literature as contained in published and unpublished materials. The outcome of the study is expected to champion the implementation of code and new urbanism that will utilize the advantages of both the form-based codes and the conventional building codes towards a sustainable living and working environment.
\end{abstract}

\section{Keywords}

Form-Based Code, Traditional Zoning Regulations, New Urbanism

\section{Introduction}

The physical built form of cities and towns has been influenced for decades by land-use planning regulations mainly traditional zoning regulations, these zoning regulations used by the local planning authority to shape urban areas by controlling and regulating land-use development to achieve desirable cityscapes 
(Helmi, 2015). However, there is an increasing concern on the undesirable effect of fast urban development, which results in urban spread that has overwhelmed the advancement of urban zones throughout the last several decades. Numerous urban and rural areas experience the hostile effects of the restrictiveness and failure of traditional zoning codes to encourage a sense of community, social and economic integration (Kim, 2010), an inadequacy of proximate administrations, a characterless urban structure, and an overdependence on cars for mobility. Additionally, it plays a part in sprawl development by the random pattern of land uses that results over time, promotion of single-use zones, separation by land use, separation of buildings by minimum setbacks, separation of buildings through large off-street parking area requirements, limiting the enclosure of pedestrian open spaces and minimum lot size requirements (Talen, 2013), all that presented many challenges to creating attractive, walkable and sustainable urban environment that encourage community's sense of place, function, high quality of life and livability (Woodward, 2012). To handle these issues, professionals in the built environment comprising of urban planners, architects, developers, and policymakers have thought on another type of urban development concept that focuses on including a variety of housing types and services in complete and compact neighborhoods. To achieve this type of community, some urban planners are considering form-based codes to guide and regulate development. Form-based codes are methods of regulating urban development to accomplish a predefined urban structure. It creates a predictable public realm by basically controlling the physical structure, with less consideration on the utilization of the land. This is a departure from existing development regulations, known as zoning, which typically focuses on land use with little control or consideration on the urban form (Cornelius \& Rob, 2010). Zoning is utilization governments organize places of living and the most well-known kind of zoning is the used-based zoning which is mostly organized into residential, commercial and industrial. Form-based code is the opposite of used based zoning. The former focuses on how the built environment will look like, while the latter is concern with the use of each plot of land (Ben, 2014). The principal emphasis of form-based codes as pointed out by the Chicago Metropolitan Agency for Planning CMAP (2013), is to shape the physical form of the built environment and to create a good urban design and architectural character by focusing on design rather than use (Pat, Eunsil, \& Maleah, 2015). Form-Based Code is in support of a new form of urbanism that promotes placed-based planning and development, not suburban or urban sprawl (Parolek et al., 2008) which have been embraced over the last three decades as an effective urban design approach and furthermore as an alternative design tool for the conventional zoning codes across urban communities in the North America. Similarly, another author argued further that the "New Urbanism" of the 1980s introduced Form-Based Code as alternative urban regulations across the US that consider the visual impact of buildings, parking and the public space such as sidewalks and streets (Donovan, 
2014). New urbanism seeks to redefine the nature of urban built environment by reintroducing traditional concepts of neighborhood plan and fitting those ideas into urban regulations. According to William Fulton (2019), new urbanists view the decentralized, auto-oriented suburb as a recipe for disaster, therefore, seek to redefine urban regulations to integrate different types of land uses at the neighborhood level for the walkable and sustainable built environment.

However, the traditional zoning regulations have been in used for a long time and customarily placed emphasis on the safeguarding of public health, safety, and welfare by setting apart residential land use from other uses such as industrial or commercial uses (Parolek et al., 2008). Therefore, it assumed a very significant role in shaping the urban environment also, by making it favorable for human activities. The traditional zoning regulation has been viewed to be rigid by critics, this is because it separates development by land use, it has been faced with criticism for its negative impacts on the built environment. It is in response to the observed constraints of the traditional zoning codes, that others like alternative codes, form-based codes, and smart codes emerged to challenge the idea of separated development by land use only, as highlighted by the traditional zoning codes. So, as communities' demand for vibrant public spaces, walkability and a sense of place, traditional zoning is seen as a barrier, do not promote the type of development envisioned by a community's comprehensive plan and even when created with the best of intentions, they can undermine the very plans they are supposed to support. Hence, this study intends to undertake a comparative review of the traditional zoning regulation and form-based codes. The comparative review seeks to carefully study the form-based codes and the traditional zoning codes with the aim of identifying the prospects and constraints of both codes and of its implementation. To achieve the study will seek to answer the following questions; what are the features of the traditional zoning regulation and the form-based codes? What are the shortcomings and advantages of the two zoning regulations? And what are the prospects of its implementation?

\section{Form-Based Codes}

The historic context and origin of Form-Based Codes can be traced as early as 1960s when planners began to recognize that the traditional (conventional) zoning that dominated during the twentieth century had resulted to negative effects on urban and suburban forms and in response to these issues, Form-Based Codes were promoted as the antidote by focusing on the physical urban form (Kim, 2010). In 1982, Seaside, Florida, planned by Andre Duany and Plater-Zyberk, was one of the early attempts to suggest a form-based approach to creating more revitalized communities. In the 1990s, several cities and counties began adopting form-based code (Parolek et al., 2008). The authors further stated that in 1993, Congress for the New Urbanism (CNU) supported form-based code and suggested several aims: visual harmony in the public realm, continuous urban frontage for uniformity, and sensitivity to spatial context. Re- 
cently, form-based code emerged as the preferred instrument for implementing new urbanist ideas of all scales and as multi-disciplinary codes that connect the design of circulation and public space networks to the design of building form (Altman et al., 2003).

According to the Form-based codes Institute, form-based codes which are also referred to as design codes or development codes, symbolize the relationship between building facades and the public realm, the form and mass of buildings in relation to one another, the scale and types of streets and blocks by using both visual diagrams and words (FBCI, 2016a). Form-based codes which stand as an alternative to conventional zoning, it functions as a template whereby having clear controls on building form, landowners and their neighbors can easily predict what future development would look like. As distinguished from design guidelines which are more advisory, form-based codes have more prescriptive and regulatory characteristics. The Form-Based Code Institute (FBCI) further explains that the codes are drafted to achieve a community vision based on time tested forms of urbanism, the quality of development outcomes is dependent on the quality and objectives of the community plan that a code implements (FBCI, 2016b).

However, traditional zoning regulations are the most widely regulatory tools used by cities across the world to manage land use development and differed as the communities that implement them. It evolved out of urban reform movements of the mid-twentieth century to address overcrowding and to protect existing residential and commercial neighborhoods from infringing development. Zoning is used in the regulation of the location, type, and density of development within a community through the delineation of one or more zones or zoning districts, as depicted on a zoning map. These regulations typically incorporate the following, in some form, Statutory Approvals, which comprises of acceptance and effective dates and use for local regulation, and bylaw amendment and provisions that apply in the event that portions of the regulation are deemed by the courts to be invalid. Zoning Districts, which includes lists of uses allowed within each zoning district (such as, permitted uses requiring only administrative review and conditional uses requiring additional board approval), related density standards (for example, minimum lot size, frontage, setback, and coverage requirements), and any other standards that are specific to each district (Ashton, 2010). Traditional zoning regulations have been criticized for lack of design consideration, inefficient land use and serious social segregation which are intended to protect the health and welfare of residents by setting clear boundaries between residential areas and industry to lower negative impacts on housing quality (Carmona, 2009). The advantages of traditional zoning regulations include little disturbance of different land uses, low transaction costs, ease of implementation, long-established legal precedent and transparent information flow. We argue that zoning reduces risks and uncertainties associated with development decisions, and thus decreases developers' planning cost so that de- 
velopers have more development money to make a primary investment which would increase the sequence of development projects under consideration. Traditional zoning has received criticism for its lack of flexibility, inefficient land use primarily characterized by difficult household-workplace commuting and institutionalization of now-outdated planning theory thereby unwittingly promote sprawl (Lai \& Han, 2012).

On the other hand, Form-Based Codes are achieved through organized principles and some optional components that are employed to implement a community's vision-based physical plan, these principles that are derived from the research and best practices of Form-Based Codes around the world, are the guiding components that define the planning and implementation of Form-Based Codes for application in various urban communities. Michigan Association of Planning (2007) argued that an important aspect of a form-based code is that all the components are tied together, the use is tied directly to the building type, the building type in-turn dictates form, building elements, and the building form also relates to the street frontage. Therefore, these essential components (Table 1) are necessary for an effective $F B C$ application.

Once the city creates a vision to adopt Form-Based Codes, it can pick and choose principles to be adopted which can help in realizing the vision and determine the design components. Some of the guiding principles coordinate built

Table 1. Elements of Form-Based Codes (FBCI, 2016a).

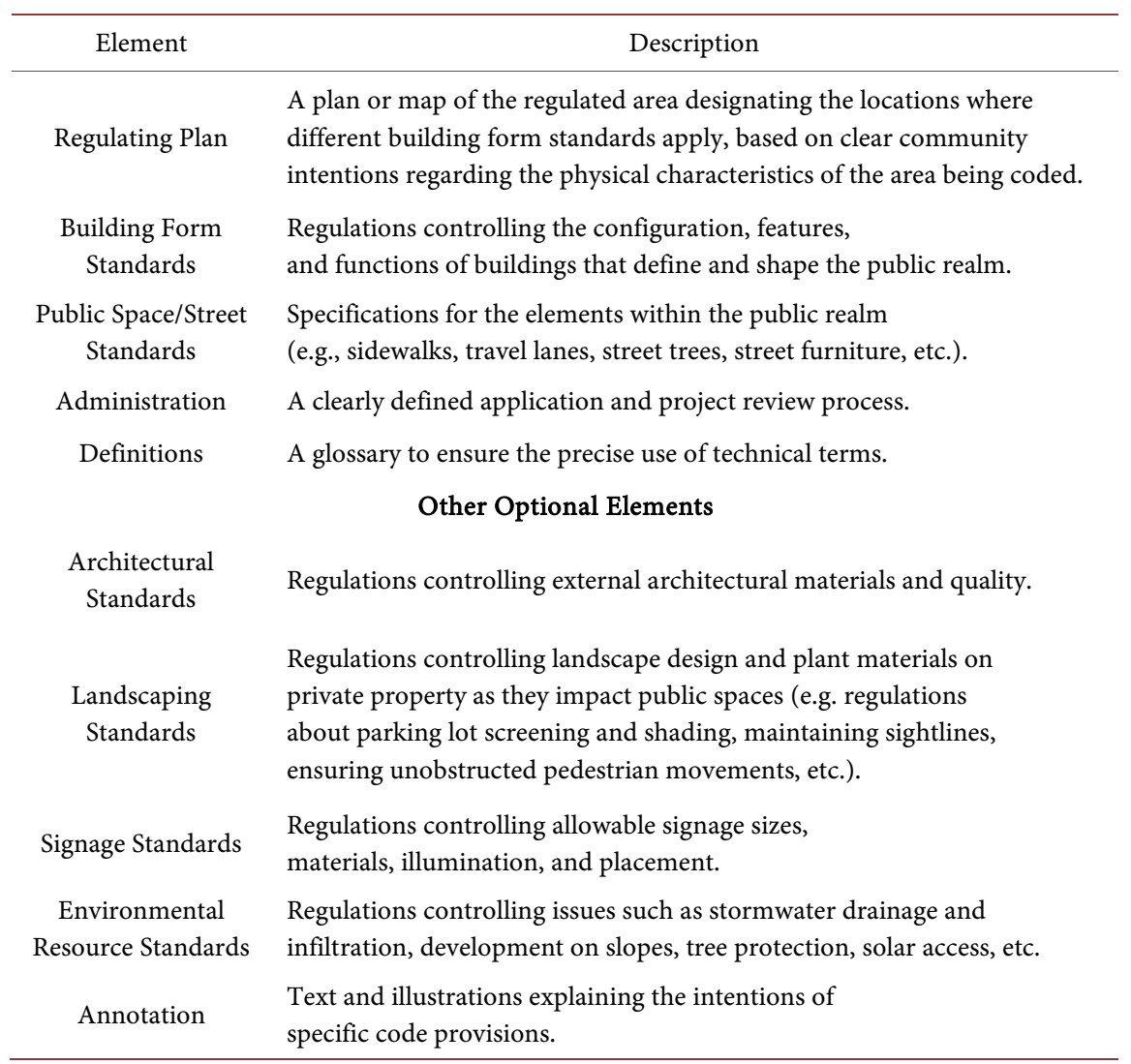


form which addresses the nature and characteristics of the built form, the correlation with the surrounding buildings and activities, complete streets that are designed and operated to enable safe, attractive, and comfortable access and travel for all users and modes (Mullins, 2010). Also, the form supports accessible public spaces that are contextually designed and located in the form of open spaces, parks and other civic spaces that help create liveable neighborhoods. Other guiding principles include; effective mobility management which focuses on creating strategies to reduce travel demand or to redistribute this demand in space or in time, through effective methods like use of public transport and discouraging private transport and environmental and cultural inclusivity which addresses the need to preserve and incorporate unique cultural and societal attributes of regions into the spatial order. Moreover, when developing Form-Based Codes a great commitment is needed for the creation of better places. A determination needs to be made on the type of code desired and the geographic area to be covered. The form-based code could be integrated into a community-wide ordinance, or perhaps applied to a specific corridor, neighborhood, or business district.

\section{Advantages and Shortcomings of Form-Based Codes}

Form-based codes tend to achieve a more predictable physical outcome as a result of their prescriptive disposition (stating the desirable), rather than prescriptive (stating the undesirable). The elements controlled by form-based codes are those that are most essential to the shaping of a high-quality built environment. Form-Based Codes support public participation thereby allowing citizens to have a clear picture of the result which leads to a higher comfort level. Because they can regulate development at the scale of an individual building or lot, Form-Based Codes encourage independent development by multiple property owners. This obviates the need for large land assemblies and the megaprojects that are frequently proposed for such parcels. The built results of Form-Based Codes often reflect a diversity of architecture, materials, uses, and ownership that can only come from the actions of many independent players operating within a community agreed-upon vision and legal framework (Katz, 2004).

Non-professionals think that it is simpler to utilize Form-Based Codes than the traditional zoning documents because since they are substantially more concise, organize and sorted out for visual access and readability. This feature makes it easier for non-planners to determine whether compliance has been achieved. FBCs removes the need for design guidelines, which are hard to apply, offer too much room for subjective interpretation, particularly without powerful and effective guidelines, and can be hard to uphold. They also require less oversight by regulatory review bodies, fostering a less politicized planning process that could deliver huge savings in time and money and lessen the danger of takings challenges. Form-Based Codes may prove to be more enforceable than design guidelines. The stated purpose of FBCs is the shaping of a high-quality public realm, a 
presumed public good that promotes healthy civic interaction. For that reason, compliance with codes can be enforced, not because of aesthetics but based on a failure to comply would diminish the good that is sought (Katz, 2004).

Meanwhile, authors like Madden et al. (2006) pointed out some of the shortcomings of form-based codes based on the time and the cost required throughout the process. Firstly, he argued that a certain amount of cost ought to be required to realize the benefits of form-based codes, and sometimes this cost will be a lot greater than the cost of traditional zoning regulations. Secondly, on the ground that many local government officials do not understand form-based codes, hence, takes more time for developers to reach consensus with communities and local governments for final approval of development projects. These administrative and time costs may be in most cases beyond the capacity of some developers. Likewise, since they have inherent uncertainty, form-based codes require patience and perseverance on the part of the participants if the process is to be followed. Thirdly, due to their indifference toward the long-term vitality of the community and fear of the risk of an alternate development, developers much of the time would prefer not to change their traditional zoning approach into a form-based code approach since they are not willing to fully understand form-based codes, which seem daunting and risky for them to apply to their development. In the case of professionals, the prescriptive and rigid nature of form-based codes creates architectural restrictiveness constraining the process of architects by forcing a narrow range of design options, which may be viewed by developers as a limitation on what they can do with their property. Therefore, it can create vague towns with a uniform aesthetic forcing cities to accept the transect as a universal city theme that are of little help in towns lacking character, delay the entitlement process with strict regulations and unreasonable variances, incorporate incomprehensible jargon, and promote density and population increases to the detriment of locals (Perez, 2014).

Furthermore, the proponents of form-based codes mentioned that the form-based codes in the urban planning history emerged as a response to problems of traditional zoning, traditional zoning regulations did not exclude a form-based approach due to preference of a use-based approach (Donovan, 2014), for example, most State Zoning Enabling Act has made provision for many physical design components such as height, number of stories, size, lot coverage, density, and location of structure.

\section{Comparative Review of Form-Based Codes and Traditional Zoning Regulations}

Traditional zoning regulation has been in use for a long time and has assumed a very significant role in shaping the urban environment, by making it favorable for human activities though it has been viewed to be inflexible by critics. On the other hand, a careful review of the principles of form-based codes shows that it provides a better-built environment than traditional zoning that is clearly asso- 
ciated with automobile-dependent urban areas, land-consumptive, environmentally degrading, single-use, homogeneous, inaccessible development with a low-quality, poorly conceived public realm (Parolek et al., 2008; Crawford, Lee, \& Beatty, 2015). Also, Michigan Association of Planning (2007) added that the traditional zoning has limited ability to effect change, as it tends to prohibit development that is determined to be inappropriate. In contrast to the traditional zoning (Table 2) that focuses on what uses are not allowed, rather than encouraging what the community requires. Form-Based Codes provide a more foreseeable result of the built environment by using its own mechanisms which comprise of public space standards, building form standards, and architectural standards to focus on what the community requires. This further implies that the form-based codes try to control building forms directly with the use of detailed design standards. Consequently, Form-Based Codes emphasizes the importance of physical form, its placement and how it relates to the public streetscape of the built environment above use. To define the streetscape, form-based codes often prescribe build-to-lines where buildings are required to be set a specific distance from the front lot line, traditional zoning uses minimum setbacks to create building envelopes; however, the ultimate location and form of the

Table 2. Traditional zoning and form-based codes comparison (Parolek et al., 2008).

\begin{tabular}{|c|c|}
\hline Traditional Zoning Regulation & Form-Based Codes \\
\hline Based on the segregation of uses & Based on the compatibility of uses \\
\hline $\begin{array}{l}\text { Often encourages excessive land } \\
\text { consumption and automobile dependency }\end{array}$ & $\begin{array}{l}\text { Encourages a mix of land uses, often } \\
\text { reducing the need to travel extensively } \\
\text { as part of one's daily routine }\end{array}$ \\
\hline $\begin{array}{l}\text { Proscriptive regulations: Regulate } \\
\text { what is not permitted }\end{array}$ & $\begin{array}{l}\text { Prescriptive regulations: Describe } \\
\text { what is required }\end{array}$ \\
\hline $\begin{array}{l}\text { Ends up focusing on what uses are } \\
\text { not allowed, rather than encouraging } \\
\text { what the community requires }\end{array}$ & Focuses on what the community requires \\
\hline $\begin{array}{l}\text { Preparation process includes minimal } \\
\text { public participation }\end{array}$ & $\begin{array}{l}\text { Community input, public participation, } \\
\text { interaction an integral part of the process }\end{array}$ \\
\hline $\begin{array}{l}\text { Presented in the form of text, numbers, } \\
\text { and tables; lacks ease in comprehensibility. } \\
\text { Also making it easier to flout, difficult to } \\
\text { monitor and enforce }\end{array}$ & $\begin{array}{l}\text { In addition, also illustrates graphically } \\
\text { (maps, sketches, etc.) making it clearer, } \\
\text { easier to decipher. Easier to enforce, } \\
\text { identify non conformity }\end{array}$ \\
\hline $\begin{array}{l}\text { Different departments for review and } \\
\text { sanction of development proposals }\end{array}$ & $\begin{array}{l}\text { Special dedicated body to guide applicants, } \\
\text { interpret, review, approve and monitor } \\
\text { development proposals }\end{array}$ \\
\hline $\begin{array}{l}\text { Current Zoning/Development } \\
\text { Control Regulations }\end{array}$ & Form-Based Codes \\
\hline $\begin{array}{l}\text { Traditional codes focus on land use } \\
\text { segregation }\end{array}$ & $\begin{array}{l}\text { A form-based code focuses on how } \\
\text { development relates to the context of the } \\
\text { surrounding community }\end{array}$ \\
\hline
\end{tabular}


building within the envelope are unpredictable. As a result, traditional zoning has a primary focus on the lot and pays little to no attention to the streetscape. Form-based codes take a more holistic approach by considering the building form as it relates to the streetscape. The focal point of form-based codes is to design a community or area of land-based on a predictable outcome designed by a community, rather than based on the separation of uses, as that of traditional land-use planning. This New Urbanism approach is hinged on the idea that physical form is a community's most essential and enduring feature (Ashton, 2010). In this approach, Form-Based Codes are well-suited with the philosophy behind designating historic districts, because they both place the greatest importance on community character through protection of the built environment, and the creation of new buildings that are pleasing to the community and based on their own perception of how their town should look and feel. In a historic district, the emphasis on what creates a community is placed on the existing built environment, and new buildings within the district must be compatible and approved by a community nominated regulating body. The Code addresses the relationship between building facades and the public realm, the form and mass of buildings in relation to one another, and the scale and types of streets and blocks, therefore, describe the desired urban form that result in the development of neighborhoods that encourages pedestrian activity, social interaction, and local investment (Katz, 2004). In addition, greater emphasis is placed on character, building features and the public spaces rather than traditional zonings that emphasis on the use of buildings.

The effectiveness of form-based codes based on a comparison between the two regulations was considered using the Fort McPherson development plan (Kim, 2010). Based on comparative assessment and application of standards to Fort McPherson area, there is not too much difference between the two regulation systems in terms of sustainability as they both seek to create environmentally friendly living places and since both systems do not have the same standards for improving sustainability in the development area, the only difference between the two is shown in the estimated total front, side, and back yard area that can be used as green space. Based on this evaluation parameter, it is found that the form-based codes improve more amenities within the residential lot and help residents enjoy their private life in their lot area. Also, several differences were observed between the traditional zoning and the form-based codes in terms of circulation, looking at the number of intersections in the Fort McPherson area shows that more intersections and blocks are created in the form base code. By cutting down the block width and increasing the number of intersections, the form-based codes have the potential to create provision for more street activities, which will result in more physical interaction among residents and improve public safety on the street. Form-based codes help to design streets with more mobility options.

It was further observed that that not all standards of the form-based codes are 
always better than traditional zoning. The traditional zoning has more possibilities for variation of lot sizes because it has different land area requirements and layout conditions based on the zoning areas. Also, as a result of the variation in land allocation, building types within the residential area can be easily identified and modified depending on the lot shape. This feature is also found in form-based codes where there is flexibility in the lot variation, but the lot size variations tend to be uniform throughout the site, which makes continuous building types and frontages by compacted building walls critical in designing the site. The form-based code has flexibility under the same lot size or area conditions, whereas the conventional zoning changes the lot requirements or site design standards suitable for the diverse building shapes or appearances. Nevertheless, development patterns based on the form-based codes encourage more mixed-use development by providing the mixed-use ratio of buildings area vertically as well as horizontally, whereas the traditional zoning have relatively limited mixed-use development controls because the traditional zoning is based on the principle of separating land and building uses for public safety, public health, and welfare.

\section{Conclusion}

Through a research review, it is found that form-based codes have existed throughout urban planning history and that they are not a replacement for traditional zoning but can be a compliment to the traditional zoning in the 21st century urban planning and design that requires the input of locals, planning authorities and expertise/professionals in its successful implementation. Also, a solid partnership amongst the stakeholders can provide a good approach to share best practices related to the code and which helps the uppermost quality process and eventually urban environment. So, Form-Based Codes can create a more holistic way to develop a desired urban form, walkable, pedestrian-friendly, and interactive community that provides a means to represent the community's vision. Therefore, urban planners and designers should find out the way of converging design standards and form-based codes components with traditional zoning regulations in this aspect to provide more powerful urban tools for a more flexible and attractive public realm as well as mixed-use development pattern for diverse building uses, sustainable and vibrant urban communities. Lastly, Form-Based Codes may not decisively be the fix it all for all the urban issues related to traditional zoning but have challenged current conventional approaches to zoning and have prompted dynamic awareness with respect to land regulations, community building, and public participation and investment. As an ever-increasing number of urban communities try to address the urban issues related to traditional zoning, Form-Based Codes will spread in application and will be recognized by many communities advocating sustainable communities for the standpoint it offers in reevaluating current traditional zoning regulations. 


\section{Conflicts of Interest}

The authors declare no conflicts of interest regarding the publication of this paper.

\section{References}

Altman, R., Crawford, P., Duany, A., Hall, L., Lawton, S., \& Sargent, D. (2003). White Paper on Smart Growth Policy in California. Prepared for the State of California, Governor's Office of Planning and Research.

Ashton, E. M. (2010). Form-Based Codes and Historic Preservation: Recommendations for Communities Considering the Adoption of Form-Based Codes. Thesis, Athens, GA: Graduate Faculty of the University of Georgia.

Ben, K. (2014). Explaining Form-Based Zoning. https://medium.com/corridor-urbanism/explaining-form-based-zoning-1df55a1d6dba

Carmona, M. (2009). Design Coding and the Creative, Market and Regulatory Tyrannies of Practice. Urban Studies, 46, 2643-2667. https://doi.org/10.1177/0042098009344226

Chicago Metropolitan Agency for Planning CMAP (2013). Form-Based Codes: A Step-by-Step Guide for Communities.

http://formbasedcodes.org/content/uploads/2013/11/CMAP

Cornelius, N., \& Rob, H. (2010). Comparison of Parking Requirements in Zoning and Form-Based Codes. Transportation Research Record Journal of the Transportation Research Board, 2187, 138-145.

Crawford, P., Lee, E., \& Beatty, M. (2015). Aesthetic Perception of Urban Streetscapes and the Impact of Form-Based Codes and Traditional Zoning Codes on Commercial Signage. Current Urban Studies, 3, 199. https://doi.org/10.4236/cus.2015.33017

Donovan, M. (2014). Community Planning New Hampshire. New Hampshire.

Form-Based Codes Institute FBCI (2016a). Form-Based Codes Defined. http://formbasedcodes.org/definition

Form-Based Codes Institute FBCI (2016b). Identifying \& Evaluating Form-Based Codes. http://formbasedcodes.org/identifyingevaluating

Fulton, W. (2019). The New Urbanism Challenges Conventional Planning. https://www.lincolninst.edu/publications/articles/new-urbanism-challenges-conventio nal-planning

Helmi, M. R. (2015). The Ability of the Local Planning Authority to Implement Zoning Regulations: A Case Study of Jeddah, Saudi Arabia. PhD Thesis, Newcastle upon Tyne: Newcastle University.

Katz, P. (2004). Form First: The New Urbanism Alternative to Conventional Zoning. Planning, 70, 16-21.

http://www.fltod.com/research/about_form_based_codes/form_first.pdf

Kim, K. (2010). The Evaluation of the Impact of Form-Based Code and Conventional Zoning on Fort Mcpherson Redevelopment. Thesis, Atlanta, GA: Georgia Institute of Technology.

Lai, S. K., \& Han, H. (2012). On Failure of Zoning. International Journal of Society Systems Science, 4, 20-27. https://doi.org/10.1504/IJSSS.2012.051145

Madden et al. (2006). Place-Making with Form-Based Codes. Urban Land, 65, 174-178.

Michigan Association of Planning (2007). Smart Growth Tactics (pp. 7-14, 28).

http://www.planningmi.org 
Mullins, A. E. (2010). Form-Based Codes and Historic Preservation: Recommendations for Communities Considering the Adoption of Form-Based Code. Doctoral Dissertation, Athens, GA: University of Georgia.

Parolek, D., Parolek, K., \& Crawford, P. (2008). Form-Based Codes: A Guide for Planners, Urban Designers, Municipalities, and Developers. Hoboken, NJ: John Wiley \& Sons Inc. https://doi.org/10.1080/01944360802540224

Pat, C., Eunsil, L., \& Maleah, B. (2015). Aesthetic Perception of Urban Streetscapes and the Impact of Form-Based Codes and Traditional Zoning Codes on Commercial Signage. Current Urban Studies, 3, 199-215. https://doi.org/10.4236/cus.2015.33017

Perez, T. (2014). Misconceptions about Form-Based Codes. http://formbasedcodes.org/articles/misconceptions-form-basedcodes

Talen, E. (2013). Zoning for and against Sprawl: The Case for Form-Based Codes. Journal of Urban Design, 18, 175-200. https://doi.org/10.1080/13574809.2013.772883

Woodward, K. A. (2012). Form over Use: Form-Based Codes and the Challenge of Existing Development. Notre Dame Law Review, 88, 2627. 